\title{
Effects of organic-matter application on phosphorus adsorption of three soil parent materials
}

\author{
W. Yu, X. Ding, S. Xue, S. Li, X. Liao, R. Wang* \\ Guangdong Key Laboratory of Agricultural Environment Pollution integrated control, Guangdong Institute of Eco-Environmental \\ and Soil Science, Guangzhou, China.*Corresponding author: rongpingwang@yeah.net
}

\begin{abstract}
In this study, poultry manure compost and organic fertilizer were added to soils derived from basalt, granite, and river alluvial deposits for use as soil parent materials. Following incubation periods of 30 or 60 days at $25^{\circ} \mathrm{C}$, the physical and chemical properties and adsorption characteristics of the soils were studied. The results indicated that the application of poultry manure compost or organic fertilizer increased the available phosphorus $(\mathrm{P})$ and organic matter content in all soils; however, the quantity of $\mathrm{P}$ and organic matter decreased with an increase in incubation time. The organic materials added via the treatments reduced the strength of $\mathrm{P}$ adsorption by the soil derived from basalt. For soils derived from granite and river alluvial deposits, the strength of $\mathrm{P}$ adsorption declined after poultry manure compost was added, but increased after the application of organic fertilizer. All soil treatments derived from basalt fitted well with the three adsorption isotherm equations. For soils derived from granite and alluvial deposit as parent materials, the data conformed to the three adsorption models in the order: Langmuir $>$ Freundlich $>$ Temkin. The maximum phosphate buffering capacity (MPBC) and standard P retention (SPR) of soil derived from basalt decreased following the application of poultry manure or organic fertilizer, whereas changes in MPBC and SPR for soils derived from granite and alluvial deposits were dependent on the organic content and incubation time.
\end{abstract}

Keywords: Soil, parent materials, organic matter, phosphorus adsorption strength, equation-fitting 


\section{Introduction}

Phosphorus (P) is one of the most abundant elements and is essential for plant growth as well as an important component in the developmental processes of agricultural crops (Zhuo et al., 2009a; Withers et al., 2008) Approximately two-thirds of inorganic $P$ and one third of organic $\mathrm{P}$ are not available in soil, especially in soils of variable charges. The rate of $\mathrm{P}$ use during crop growth is very low. Phosphates fixed by $\mathrm{Fe}, \mathrm{Al}$, and $\mathrm{Ca}$ in soils is a major cause of low phytoavailability (McBeath et al., 2005), because at least $70-90 \%$ of $\mathrm{P}$ that enters the soil is fixed, making it difficult for plants to absorb and use (Kou et al., 1999; Lei et al., 2004; Liu et al., 2000). Therefore, research by pedologists and plant nutritionists has primarily focused on the issue of increasing the $\mathrm{P}$ use-rate of plants, both at local and international scales. Resolving this issue is fundamental towards the continued development of agriculture.

Organic supplements have been reported to increase $\mathrm{P}$ availability in P-fixing soils (Iyamuremye and Dick, 1996; Guppy et al., 2005; Agbenin and Igbokwe, 2006; Gichangi, 2009) and humic substances enhance the bioavailability of $\mathrm{P}$ fertilizers in acidic soils (Hua et al., 2008). Decomposition products from manure such as humic acids and citrate were reported to have greater affinity for $\mathrm{Al}$ oxides than for $\mathrm{PO}_{4}$ (Violante and Huang, 1989). Various researchers have investigated the activity of $\mathrm{P}$ in soil from the perspective of low-molecular-weight (LMW) organic acids, the incorporation of different organic fertilizers, and soil types. The addition of LMW organic acids activates Al-P and Fe-P in neutral and acidic soils and Ca-P in alkaline soil (Zhuo et al., 2009b; Zhang et al., 2009), causing an increase in the levels of readily-available P for use by plants. Ma et al. (2010) reported that the addition of straw during cultivation reduces $\mathrm{P}$ adsorption in red and paddy soils, but has a smaller effect on latosol. Bolster and Sistani (2009) studied the effects of swine, cattle, and poultry manure extracts on $\mathrm{P}$ adsorption in different soil types. The authors found that the $\mathrm{P}$ adsorption capacities of soils were dependent on the type of organic fertilizer applied and the available soil type. Other studies have shown that when poultry, cattle, and goat manure are applied to highly weathered tropical soil, the P-sorption efficiency of the soil and P-buffering capacity decreased with an increasing incubation period (Azeez and Averbeke, 2011). Variations in organic products from supplements have also been reported to influence P sorption (Hue, 1991).

A number of models have been developed (Kinniburgh, 1986; McGechan and Lewis, 2002) to quantitatively describe the sorption isotherm, the most popular being the Langmuir (Pant and Reddy, 2001; Essington, 2003; Dossa, 2008) and the Freundlich equations (Donald, 2003; Essington, 2003). These studies have highlighted that $P$ sorption can be explained quite satisfactorily by using different isotherm equations, but that no single equation can be considered suitable for all soil types. Little has been reported on the $\mathrm{P}$ sorption of soils fertilized with manure for different incubation periods.

In China, the soil of vegetable fields is an important component for the continuation of agricultural development. Due to the over-fertilization of vegetable fields over long periods, the nutritional content of these soils has become highly imbalanced and very different from that of normal agricultural soils. However, only few studies have been conducted on the soils in which vegetable crops are grown. Therefore, in this study, the three typical parent materials (basaltic, granitic, and river alluvial deposits) on which vegetable crops are grown in the Pearl River Delta of China were used as test materials. Through laboratory-based experiments, we studied the effects of adding different organic fertilizers, followed by an incubation period of 30 or 60 days, on the $\mathrm{P}$ adsorption activity of the three soil types. The findings of this study are expected to provide a theoretical basis for the rational application of organic fertilizers to these types of soil. Consequently, this 
study was conducted to evaluate the effects of two organic fertilizer incubated periods of 30 or 60 days on the P-sorption indices of different parent materials.

\section{Materials and Methods}

\subsection{Test Materials}

Soils derived from basaltic, granitic, and alluvial parent materials were obtained from Zhanjiang City in Xuwen County, Guangzhou City in Huadu District, and Foshan City in Nanhai District, respectively. All soil types were composed of $0-20 \mathrm{~cm}$ topsoil. The soil samples were air-dried naturally and passed through a $2 \mathrm{~mm}$ sieve in preparation for use. The basic physical and chemical properties of the test materials are shown in Table 1. The measurements of $\mathrm{pH}$, organic matter, total phosphorus and alkaline hydrolysable nitrogen were conducted according to the literature (Jackson, 1973). The available phosphorus was determined using the Olsen method (Olsen et al.,
1954). The measurementof free iron oxides was conducted with reference to Loppert and Inskeep (1996), and that of amorphous iron oxides, with reference to McKeague and Day (1966).

Two organic fertilizers were tested; specifically, poultry manure $\left(\mathrm{M}_{1}\right)$ and commercial organic fertilizer $\left(M_{2}\right)$. The M1 fertilizer was obtained from farmyard manure in Foshan City of Nanhai District, whereas $\mathrm{M}_{2}$ (Zhuang Gen Bao refined organic fertilizer) was purchased commercially from the Fertilizer Industry Co. Ltd., Dongguan City. The test fertilizers were airdried and passed through a $0.25-\mathrm{mm}$ sieve before use. The physical and chemical properties of $\mathrm{M}_{1}$ were $\mathrm{pH}$ $=8.02$, total $\mathrm{P}=1.65 \%$, and available $\mathrm{P}=9.55 \mathrm{~g} \bullet \mathrm{kg}^{-1}$. The physical and chemical properties of $\mathrm{M}_{2}$ were $\mathrm{pH}$ $=6.87$, total $\mathrm{P}=0.66 \%$, and available $\mathrm{P}=4.20 \mathrm{~g} \bullet \mathrm{kg}$ 1. The $\mathrm{pH}$ of manure solutions was measured using an Orion combination $\mathrm{pH}$ probe (Thermo Electron Corp., Beverly, Mass.). Total P and available P were analysed in triplicate using ICP-OES.

Table 1. Baseline physical and chemical properties of the test materials.

\begin{tabular}{|c|c|c|c|c|c|c|c|c|c|c|}
\hline \multirow{2}{*}{$\begin{array}{c}\text { Soil Parent } \\
\text { Material }\end{array}$} & \multirow[b]{2}{*}{$\mathrm{pH}$} & \multicolumn{2}{|l|}{ Available } & \multirow{2}{*}{$\begin{array}{l}\text { Organic } \\
\text { Matter } \\
\left(\mathrm{g} \cdot \mathrm{kg}^{-1}\right)\end{array}$} & \multirow{2}{*}{$\begin{array}{c}\text { Alkaline } \\
\text { Hydrolysed } \\
\text { Nitrogen } \\
\left(\mathrm{mg} \cdot \mathrm{kg}^{-1}\right)\end{array}$} & \multirow{2}{*}{$\begin{array}{c}\text { Free } \\
\text { Iron } \\
\text { Oxide } \\
\left(\mathrm{g} \cdot \mathrm{kg}^{-1}\right)\end{array}$} & \multirow{2}{*}{$\begin{array}{l}\text { Amorphous } \\
\text { Iron Oxide } \\
\quad\left(\mathrm{g} \cdot \mathrm{kg}^{-1}\right)\end{array}$} & \multicolumn{3}{|c|}{ Total Amount (\%) } \\
\hline & & $\begin{array}{c}\text { P) (mg. } \mathrm{kg}^{-} \\
\mathbf{1}^{-}\end{array}$ & (\%) & & & & & $\mathrm{Fe}_{2} \mathrm{O}_{3}$ & $\mathrm{MnO}$ & $\mathrm{Al}_{2} \mathrm{O}_{3}$ \\
\hline Basalt & 4.50 & 7.93 & 0.05 & 26.62 & 160.46 & 10.58 & 2.18 & 20.43 & 0.11 & 25.43 \\
\hline Granite & 6.34 & 161.81 & 0.16 & 30.64 & 186.76 & 8.74 & 2.06 & 3.00 & 0.04 & 17.51 \\
\hline Alluvium & 6.19 & 66.58 & 0.18 & 20.48 & 130.16 & 8.50 & 1.48 & 4.79 & 0.02 & 10.70 \\
\hline
\end{tabular}




\subsection{Experimental Method}

Treatment by the Addition of Organic Materials

Six samples (300 g each) of the soils derived from the three different parent materials were passed through a 2-mm sieve before being weighed and set aside. The $M_{1}$ or $M_{2}$ fertilizers were separately added to two samples from each of the three soil groups, with an additional two samples from each of the three soil groups serving as the control, in which no fertilizer was added (CK). Nine grams of $M_{1}$ and $M_{2}$ was added to each sample. After mixing, deionized water was added until $60 \%$ of field capacity was reached, and then the surface was covered using porous plastic films. Water was replenished every other day using gravimetric methods, to maintain the initial level. The samples were incubated at $25{ }^{\circ} \mathrm{C}$ for 30 or 60 days. After incubation, the soil samples were air-dried and passed through a 0.25 $\mathrm{mm}$ sieve before use.

\section{Adsorption Test}

For each soil sample, $1 \mathrm{~g}$ was accurately weighed and placed into $100-\mathrm{mL}$ centrifuge tubes. Next, 20-mL of different concentrations of $\mathrm{P}$ solution containing $0.01 \quad \mathrm{~mol} \cdot \mathrm{L}^{-1} \quad \mathrm{CaCl}_{2}$ was added, which served as a supporting electrolyte. The $\mathrm{P}$ concentration gradient was $0,10,20,40,60,100$, and $140 \mathrm{mg} \cdot \mathrm{L}^{-1}$. The samples were shaken for $24 \mathrm{~h}(180$ r.p.m.) at a constant temperature of $25^{\circ} \mathrm{C}$, and then centrifuged and filtered. The $\mathrm{P}$ concentration of the supernatant was determined (Murphey and Riley, 1962), followed by the calculation of P-adsorption rates resulting from the different treatments. Adsorption isotherms were then plotted and fitted to the Langmuir, Freundlich, and Temkin equations. The experimental set was repeated three times. The Langmuir equation is given by $\mathrm{C} / \mathrm{Q}=1 /(k \mathrm{~b})+\mathrm{C} / \mathrm{b}$. The Freundlich equation is given by $\log \mathrm{Q}=1 / \mathrm{n} \log \mathrm{C}+\log$ $\mathrm{k}$ and the Temkin isotherm is applied in the following form $\mathrm{Q}=\mathrm{A}+\mathrm{B} \ln \mathrm{C}$.

\subsection{Data Analysis}

All data obtained from the experiments were analysed using SAS 6.12 statistical software. Significant treatments means were identified using the least significant differences (LSD) value at the 5\% level of probability.

\section{Results and Discussion}

\subsection{Changes in the Physical and Chemical Properties of the Test Materials}

Table 2 shows the soil $\mathrm{pH}$, Olsen-P, and organic matter content of the three soil types used in the different treatments, followed by 30 - or 60-day incubation periods.

The $\mathrm{pH}$ of soil derived from basalt was significantly higher in the $\mathrm{M}_{2}$ groups compared to the CK groups and the $\mathrm{pH}$ of soil derived from basalt was higher after the 60-day incubation than that after the 30-day incubation. For soils derived from granite and alluvium, the soil $\mathrm{pH}$ of the $\mathrm{M}_{2}$ groups was significantly different to that of the $\mathrm{CK}$ groups. For both of these soil types, soil $\mathrm{pH}$ decreased significantly following $M_{2}$ treatment and 30-day incubation. After 60 days of incubation, the $\mathrm{pH}$ of soil from granite was significantly lower than that in the CK groups, whereas that from alluvium was significantly higher. The addition of $\mathrm{M}_{2}$ followed by 30 or 60 days of incubation significantly increased the $\mathrm{pH}$ of both soil types.

The results show that addition of $\mathrm{M}_{2}$ followed by 30 or 60 days of incubation increased the $\mathrm{pH}$ of soil derived from basalt. Furthermore, soil $\mathrm{pH}$ was higher after 60 days than after 30 days of incubation. The basaltderived soil was strongly acidic; thus, the addition of the neutral and slightly alkaline $\mathrm{M}_{2}$ partially alleviated soil acidity, but could not achieve neutrality. For soils derived from granite and alluvium, the addition of $\mathrm{M}_{1}$ followed by 30 days of incubation reduced soil $\mathrm{pH}$, whereas 60 days of incubation increased soil $\mathrm{pH}$. 
Table 2. Changes in the physical and chemical indices following organic matter application and incubation.

\begin{tabular}{|c|c|c|c|c|c|c|}
\hline \multirow{2}{*}{$\begin{array}{l}\text { Soil Type \& } \\
\text { Treatment }\end{array}$} & \multicolumn{2}{|c|}{$\mathrm{pH}$} & \multicolumn{2}{|c|}{ Olsen-P (mg. $\left.\mathrm{kg}^{-1}\right)$} & \multicolumn{2}{|c|}{ Organic Matter $\left(\mathrm{g} \cdot \mathrm{kg}^{-1}\right)$} \\
\hline & 30 days & 60 days & 30 days & 60 days & 30 days & 60 days \\
\hline Basalt + CK & $4.28 \mathrm{f}$ & $4.32 \mathrm{e}$ & $5.32 \mathrm{e}$ & $5.73 \mathrm{e}$ & $24.28 \mathrm{~d}$ & $23.89 \mathrm{~d}$ \\
\hline Basalt $+M_{1}$ & $4.77 \mathrm{~d}$ & $4.81 \mathrm{c}$ & $76.66 \mathrm{a}$ & $72.32 \mathrm{~b}$ & $29.79 a b$ & $28.70 \mathrm{bc}$ \\
\hline Basalt $+\mathrm{M}_{2}$ & $5.02 \mathrm{~b}$ & $5.11 \mathrm{a}$ & $24.63 \mathrm{c}$ & $21.48 \mathrm{~d}$ & $27.90 \mathrm{c}$ & $30.34 \mathrm{a}$ \\
\hline $\mathrm{F}$ & \multicolumn{2}{|c|}{903.21} & \multicolumn{2}{|c|}{5228.20} & \multicolumn{2}{|c|}{33.62} \\
\hline Significance Level & \multicolumn{2}{|c|}{0.0001} & \multicolumn{2}{|c|}{0.0001} & \multicolumn{2}{|c|}{0.0001} \\
\hline Granite + CK & $6.46 \mathrm{~d}$ & $6.85 \mathrm{~b}$ & $259.13 \mathrm{c}$ & $238.59 \mathrm{~d}$ & $31.48 \mathrm{c}$ & $30.40 \mathrm{c}$ \\
\hline Granite $+\mathrm{M}_{1}$ & $6.36 \mathrm{e}$ & $6.60 \mathrm{c}$ & $425.47 \mathrm{a}$ & $361.28 \mathrm{~b}$ & $37.84 \mathrm{a}$ & $35.13 \mathrm{~b}$ \\
\hline Granite $+\mathrm{M}_{2}$ & $6.57 \mathrm{c}$ & $6.95 \mathrm{a}$ & $257.21 \mathrm{c}$ & $245.65 \mathrm{c}$ & $37.77 \mathrm{a}$ & $34.19 \mathrm{~b}$ \\
\hline $\mathrm{F}$ & \multicolumn{2}{|c|}{227.28} & \multicolumn{2}{|c|}{259.04} & \multicolumn{2}{|c|}{37.74} \\
\hline Significance Level & \multicolumn{2}{|c|}{0.0001} & \multicolumn{2}{|c|}{0.0001} & \multicolumn{2}{|c|}{0.0001} \\
\hline Alluvium + CK & $6.34 \mathrm{f}$ & $6.78 \mathrm{c}$ & $118.33 \mathrm{~d}$ & $93.30 \mathrm{e}$ & $20.53 \mathrm{~d}$ & $20.43 \mathrm{~d}$ \\
\hline Alluvium $+\mathrm{M}_{1}$ & $6.25 \mathrm{e}$ & $6.84 \mathrm{~b}$ & 260.74 a & $227.04 \mathrm{~b}$ & $24.51 \mathrm{~b}$ & $22.36 \mathrm{c}$ \\
\hline Alluvium $+\mathrm{M}_{2}$ & $6.54 \mathrm{~d}$ & $6.94 \mathrm{a}$ & $140.38 \mathrm{c}$ & $117.21 \mathrm{~d}$ & $25.02 \mathrm{a}$ & $26.47 \mathrm{a}$ \\
\hline $\mathrm{F}$ & \multicolumn{2}{|c|}{623.71} & \multicolumn{2}{|c|}{941.53} & \multicolumn{2}{|c|}{25.19} \\
\hline Significance Level & \multicolumn{2}{|c|}{0.0001} & \multicolumn{2}{|c|}{0.0001} & \multicolumn{2}{|c|}{0.0001} \\
\hline
\end{tabular}

Note: Significant differences between treatments at $p<0.05$ levels are indicated by different lowercase letters within columns.

For all soil types, soil $\mathrm{pH}$ increased after the addition of $\mathrm{M}_{2}$. Soil $\mathrm{pH}$ was also higher after 60 days of incubation than that after 30 days. These two soil types are neutral by nature. The high degree of mineralisation during the composting of $\mathrm{M}_{1}$ produced humic acid and small organic acid molecules, which reduced the soil $\mathrm{pH}$. For $\mathrm{M}_{2}$, the low degree of mineralisation caused soil $\mathrm{pH}$ to either remain neutral or to increase. Overall, changes in soil $\mathrm{pH}$ after the addition of organic fertilizers were dependent on the $\mathrm{pH}$ of the different soil types, in addition to the $\mathrm{pH}$ and extent of mineralisation of the organic fertilizer.
The Olsen P content of the three soils derived from different parent materials was $7.93,161.81$, and 66.58 $\mathrm{mg} \cdot \mathrm{kg}^{-1}$, respectively (Table 1). Table 2 shows that for the basaltic CK group, the level of available $\mathrm{P}$ decreased after 30 and 60 days of incubation, with a greater decrease after 30 days. This result indicates that between 30 and 60 days of incubation, the amount of available P increased by a small amount. In comparison, between the granitic and alluvial CK groups, the increase was greater after 30 days than 60 days. Although the amount of available P was lower at 60 days than at 30 days, the level was still higher than that in the early incubation period. 
This result indicates that P-release was greater than adsorption for soil derived from granite and alluvium in the first 30 days of incubation; however, $\mathrm{P}$ adsorption was greater than the release between 30 and 60 days.

After the addition of organic fertilizers, available $\mathrm{P}$ was significantly higher in all treatment groups compared to the CK groups, with the exception of granite + $M_{2}$. Furthermore, the increase was greater in the $M_{1}$ compared to the $\mathrm{M}_{2}$ groups. This difference might have been due to the relationship between available $\mathrm{P}$ and the different degree of mineralisation of $M_{1}$ and $M_{2}$. As the incubation time increased, available $\mathrm{P}$ decreased, with the decrease in the basaltic group being significantly smaller than that in other soil types. The granite $+\mathrm{M}_{2}$ exception might have been due to the high base levels of available $\mathrm{P}$ in the soil, such that the addition of $\mathrm{M}_{2}$ might have increased the number of sites, causing insignificant changes in the available P. Nevertheless, a small increase was still observed.

For all three soil types, the organic matter content did not change significantly for the CK groups between the start or after 30 or 60 days of incubation, indicating that soil mineralisation had a relatively small effect without organic material addition. For all treatment groups, there was a significant increase in organic matter content compared to the CK groups after the addition of organic materials at 30 and 60 days of incubation. The $M_{1}$ and $M_{2}$ groups showed similar increases in organic matter content. With the exception of the granite $+\mathrm{M}_{2}$ and alluvium $+\mathrm{M}_{2}$ treatment groups, the organic matter content of all other treatment groups after 30 days of incubation was higher than that after 60 days, which suggests that the mineralisation of organic matter occurs during the incubation process. This process might have lagged in the two treatment groups in which this effect was not recorded.

\subsection{Changes in the P Adsorption of the Test Materials}

Soil Derived from Basaltic Parent Material

The P-adsorption isotherms of soil derived from basalt that underwent treatments followed by 30 or 60 days of incubation are shown in Figure 1. Supporting the general adsorption characteristics, the $\mathrm{P}$ adsorption of the soil samples increased as the initial $\mathrm{P}$ concentration increased at lower $\mathrm{P}$ concentrations, and then increased to a lesser extent at higher $\mathrm{P}$ concentrations.

The results indicate that adding different organic fertilizers followed by 30 and 60 days of incubation decreased the $\mathrm{P}$ adsorption of all soil samples from all treatment groups. Latosol is a typical acidic soil that derives from basaltic parent materials. This soil type is rich in iron and aluminum oxides, which have high degrees of crystallinity and high P-adsorption capacities. However, the addition of organic fertilizers reduces the P-adsorption capacity of latosol. There are several possible explanations for this phenomenon. Firstly, organic acids produced by the mineralisation of organic fertilizers might compete for adsorption with $\mathrm{P}$, thereby reducing adsorption sites for P. Secondly, dissolved organic matter (DOM) produced via the mineralisation of organic fertilizers might cause soil to repulse phosphates more. Thirdly, the combination of organic fertilizers with iron and aluminum oxides in acidic soil might reduce the P-adsorption capacities of the oxides. Fourthly, the enveloping effects of organic fertilizers might reduce the $\mathrm{P}$ adsorption of the soil (Ma and $\mathrm{Xu}, 2010$; Shariatmadari et al., 2006; Hunt et al., 2007)

Further investigation is required to confirm whether one of these factors was prevalent or whether several factors acted together. Overall, the addition of organic fertilizers reduced the P-adsorption capacity of soils derived from basalt, but did not affect the basic shape of the adsorption isotherms, i.e. an initial rapid increase in adsorption followed by a smaller increase.

\subsection{Soil Derived from Granitic Parent Material}

The P-adsorption isotherms of soil derived from granite that underwent treatments followed by 30 or 60 days of incubation are shown in Figure 2. The P adsorption of the soil samples increased as initial $\mathrm{P}$ 
concentration increased. The adsorption isotherms showed a $\mathrm{H}$-shaped increasing trend, with $\mathrm{P}$ adsorption reaching a a plateau when the initial $\mathrm{P}$ concentration was about $40-100 \mathrm{mg} \cdot \mathrm{L}^{-1}$, but increased further beyond $100 \mathrm{mg} \cdot \mathrm{L}^{-1}$. The results indicate that adding $M_{1}$ followed by 30 or 60 days of incubation decreased the $\mathrm{P}$ adsorption of soil samples for all treatment groups, whereas adding $\mathrm{M}_{2}$ followed by incubation led to a smaller increase in $\mathrm{P}$ adsorption.

In addition to the relatively weaker P-adsorption capacity of granite-derived soils, Table 1 shows that the granite-derived soils have a lower iron and aluminum oxide content compared to soil derived from basalt. The $M_{1}$ fertilizer is composed of organic matter that has been partially mineralised and mainly contains inorganic carbon. Thus, the addition of $\mathrm{M}_{1}$ led to competition between the organic acids produced through mineralisation and $\mathrm{P}$, thus reducing the $\mathrm{P}$-adsorption capacity of the soil. In comparison, $\mathrm{M}_{2}$ is mainly composed of non-decomposed organic carbon. Hence, the addition of $\mathrm{M}_{2}$ increases the adsorption sites in soil, causing an increase in $\mathrm{P}$ adsorption. At the same time, mineralisation causes adsorption competition; hence, the magnitude of change is small. These results are consistent with those obtained by Zhao et al. (2006).

\subsection{Soil Derived from Alluvial Parent Material}

The P-adsorption isotherms of soil derived from alluvium that underwent treatments followed by 30 or 60 days of incubation are shown in Figure 3. The adsorption isotherm of the $\mathrm{CK}$ group after 30 or 60 days of incubation shows that $\mathrm{P}$ adsorption increased as the initial $\mathrm{P}$ concentration increased. This trend continued until the initial $\mathrm{P}$ concentration reached $60 \mathrm{mg} \cdot \mathrm{L}^{-1}$, after which $\mathrm{P}$ adsorption decreased. Subsequently, $\mathrm{P}$ adsorption once more increased together with an increase in $\mathrm{P}$ concentration.

For the $\mathrm{M}_{1}$ group, the adsorption isotherm was waveshaped after 30 or 60 days of incubation. In this case, $\mathrm{P}$ adsorption rapidly increased as the initial $\mathrm{P}$ concentration increased, then decreased, before once again increasing and decreasing. This might be due to the introduction of external $\mathrm{P}$ by the addition of $\mathrm{M}_{1}$, which, together with the mineralisation of $\mathrm{M}_{1}$, led to large fluctuations in the dynamic adsorption and desorption of $\mathrm{P}$. For the $\mathrm{M}_{2}$ group, the adsorption isotherm showed an initial increase in $\mathrm{P}$ adsorption as the $\mathrm{P}$ concentration increased, which then decreased briefly before increasing further after 30 and 60 days of incubation. This trend was also observed for the CK group.

These results indicate that although the addition of $\mathrm{M}_{1}$ might have caused a decrease in the $\mathrm{P}$ adsorption of soil derived from alluvium, it caused large changes in the shape of the adsorption isotherm. In comparison, although the addition of $\mathrm{M}_{2}$ did not cause large changes in the shape of the adsorption isotherm, it only produced a small increase in the $\mathrm{P}$ adsorption of the soil. This result might be due to the relatively weaker P-adsorption capacities of soil derived from alluvium. The addition of $\mathrm{M}_{1}$, which has a high degree of mineralisation, increased competition for adsorption sites. In contrast, the addition of $\mathrm{M}_{2}$ might have increased the number of adsorption sites in the soil, thereby increasing $\mathrm{P}$ adsorption.

The $\mathrm{P}$ adsorption of soil derived from basalt was higher than that of the other two soil types. This difference is closely related to the soil type, as well as to the physical and chemical properties of the soil. Previous studies have shown that soil $\mathrm{pH}$, together with the iron and aluminum oxide content, significantly affects the P-adsorption capacity of soils. In this study, the different P-adsorption capacities of the soils derived from different parent materials were closely related to soil $\mathrm{pH}$, in addition to iron and aluminum oxide content. Zhao et al. (2006) reported that for soils with a $\mathrm{pH}>6.0$, the organic matter in the soil increased $\mathrm{P}$-adsorption, whereas for soils with a $\mathrm{pH}<6.0$, the organic matter decreased P-adsorption. Similar results were obtained in this study. Soil derived from basalt is acidic, whereas the other two soil types are neutral, with a $\mathrm{pH}>6.0$. 

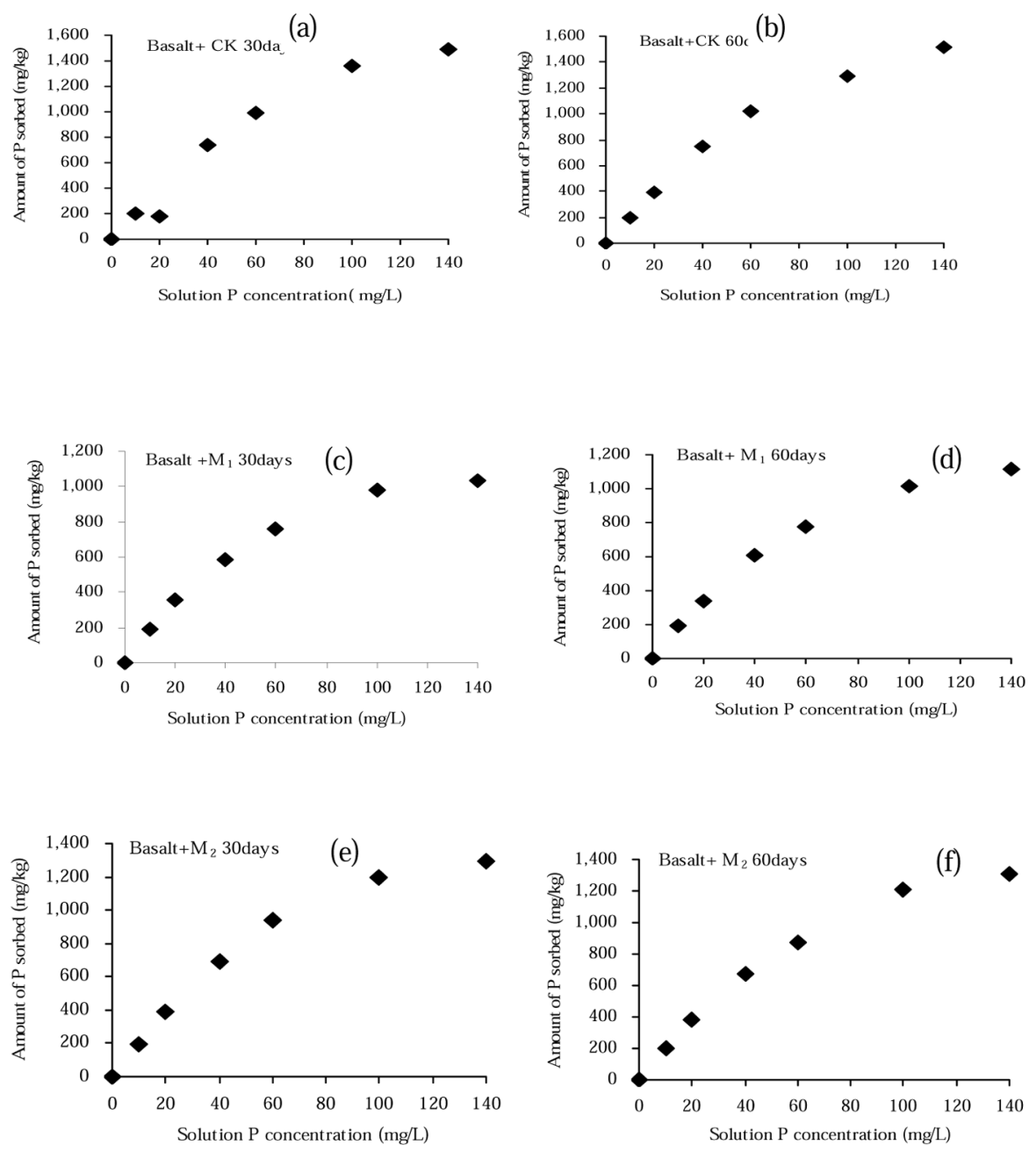

Figure 1. Adsorption isotherms of phosphorus on soil derived from basalt with organic matter application after incubation.

The addition of $\mathrm{M}_{2}$ decreased the P-adsorption capacity of soil derived from basalt, but increased that of soil derived from granite and alluvium. The addition of $\mathrm{M}_{1}$ decreased the $\mathrm{P}$-adsorption capacity of all three soil types. This result might have been due to the mineralisation of $M_{1}$, causing a large part of organic matter introduced to the soil to be t ransformed into organic acids. Adsorption competition from the organic acids was greater compared to the increase in adsorption sites, thereby causing a decrease in overall P-adsorption capacity. 

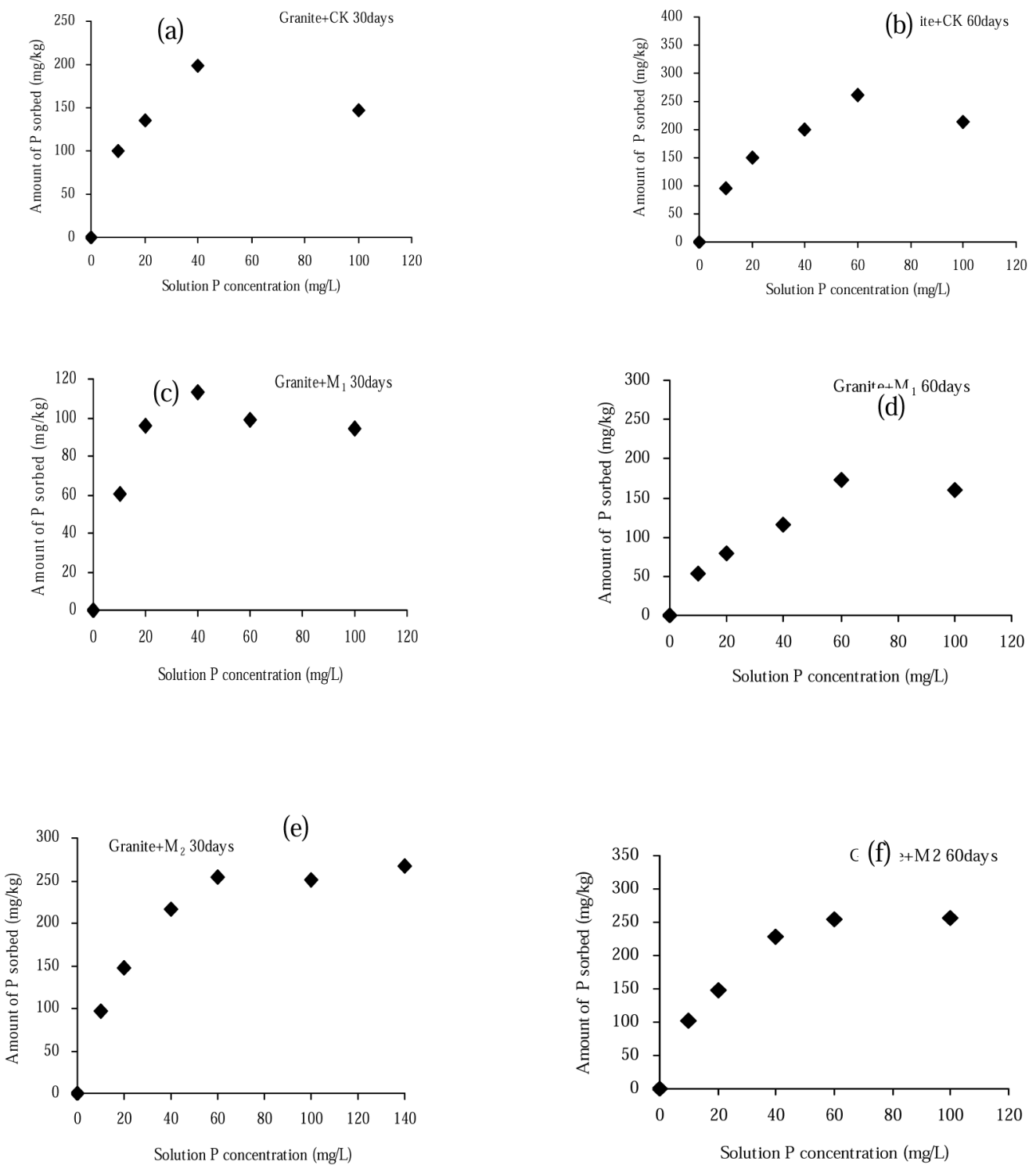

Figure 2. Adsorption isotherms of phosphorus on soil derived from granite with organic matter application after incubation. 

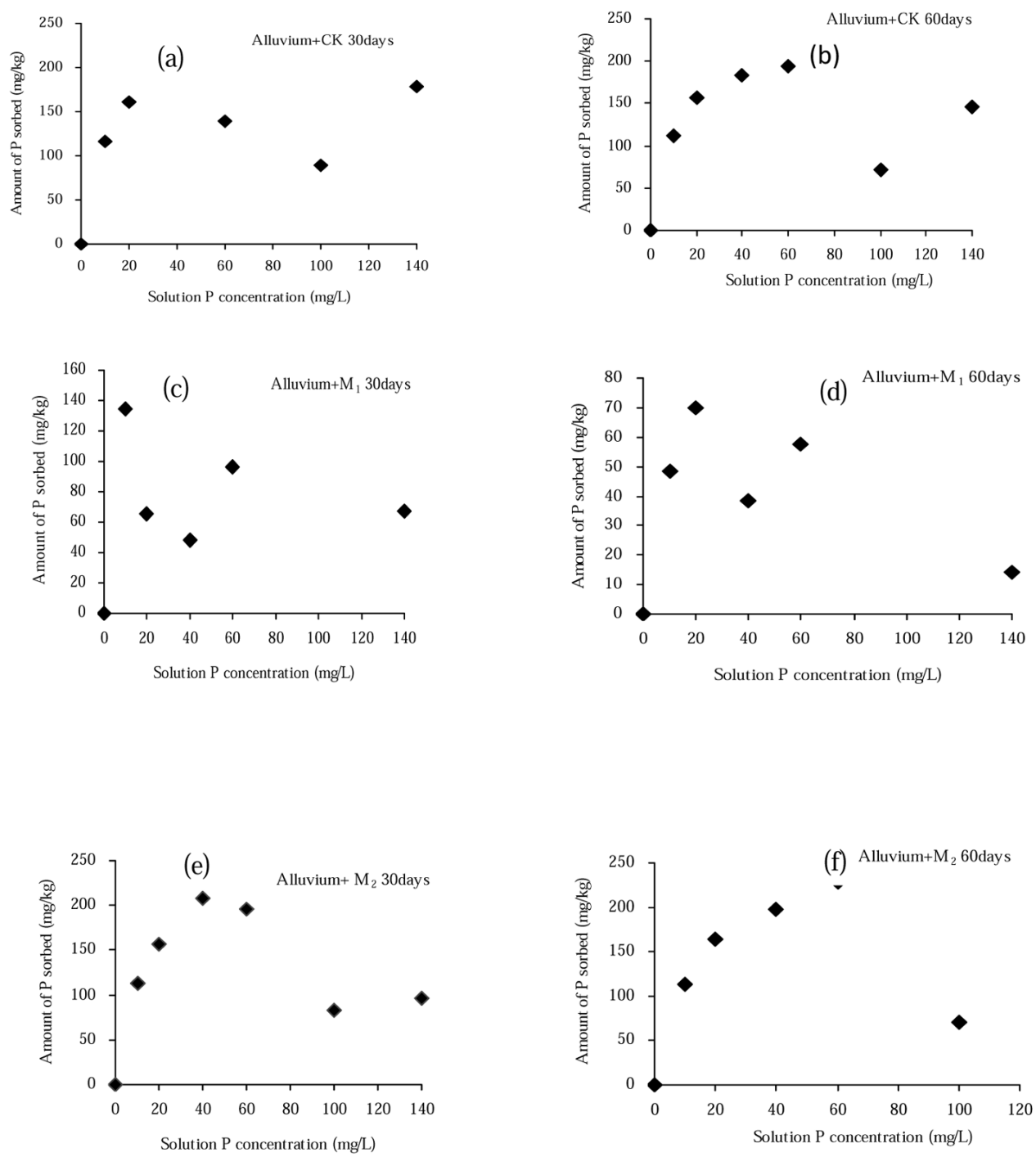

Figure 3. Adsorption isotherms of phosphorus on soil derived from alluvium with organic matter application after incubation. 
Table 3. Fitting parameters of adsorption models for the three different soil types

\begin{tabular}{|c|c|c|c|c|c|c|c|c|c|c|}
\hline \multirow{2}{*}{$\begin{array}{l}\text { Soil Type \& } \\
\text { Treatment }\end{array}$} & \multirow{2}{*}{$\begin{array}{c}\text { Incubation } \\
\text { Period } \\
\text { (days) }\end{array}$} & \multicolumn{3}{|c|}{ Langmuir Equation } & \multicolumn{3}{|c|}{ Freundlich Equation } & \multicolumn{3}{|c|}{ Temkin Equation } \\
\hline & & $\begin{array}{c}b_{1} \\
\left(\mathrm{mg} \cdot \mathrm{kg}^{-1}\right)\end{array}$ & $\begin{array}{c}\mathrm{k}_{1}\left(\mathrm{~L} \cdot \mathrm{mg}^{-}\right. \\
\mathbf{1})\end{array}$ & $\mathbf{R}^{2}$ & $\begin{array}{c}\mathrm{K}\left(\mathrm{mg} \cdot \mathrm{g}^{-1}\right. \\
\left.\left[\mathrm{L} \cdot \mathrm{mg}^{-1}\right]^{1 / n}\right)\end{array}$ & $\mathbf{n}$ & $\mathrm{R}^{2}$ & B & $A\left(L \cdot g^{-1}\right)$ & $\mathbf{R}^{2}$ \\
\hline \multirow{2}{*}{ Basalt + CK } & 30 & 1666.67 & 0.30 & 0.9932 & 634.45 & 4.93 & 0.9970 & 123.08 & 827.92 & 0.9040 \\
\hline & 60 & 1428.57 & 0.47 & 0.9899 & 587.22 & 4.33 & 0.9941 & 190.79 & 641.10 & 0.9798 \\
\hline \multirow{2}{*}{ Basalt $+\mathrm{M}_{1}$} & 30 & 1111.11 & 0.16 & 0.9925 & 263.88 & 3.07 & 0.9898 & 166.48 & 266.81 & 0.9728 \\
\hline & 60 & 1250.00 & 0.13 & 0.9914 & 245.36 & 2.78 & 0.9884 & 188.79 & 231.00 & 0.9564 \\
\hline \multirow{2}{*}{ Basalt $+\mathrm{M}_{2}$} & 30 & 1250.00 & 0.32 & 0.9952 & 405.98 & 3.43 & 0.9884 & 174.18 & 501.30 & 0.9746 \\
\hline & 60 & 1428.57 & 0.22 & 0.9886 & 384.33 & 3.35 & 0.9928 & 177.38 & 468.04 & 0.9544 \\
\hline \multirow{2}{*}{ Granite + CK } & 30 & 149.25 & -- & 0.9868 & 42.98 & 2.08 & 0.4157 & 142.40 & -- & 0.1824 \\
\hline & 60 & 322.58 & 0.06 & 0.8864 & 59.06 & 2.91 & 0.8834 & 63.48 & -- & 0.8270 \\
\hline \multirow{2}{*}{ Granite $+M_{1}$} & 30 & 97.09 & 6.44 & 0.9902 & 52.81 & 6.22 & 0.4834 & 12.54 & 50.44 & 0.4428 \\
\hline & 60 & 277.78 & 0.02 & 0.8833 & 19.87 & 1.99 & 0.9513 & 59.76 & -- & 0.8875 \\
\hline \multirow{2}{*}{ Granite $+\mathrm{M}_{2}$} & 30 & 285.71 & 0.10 & 0.9976 & 63.96 & 3.12 & 0.9094 & 55.34 & 14.35 & 0.9405 \\
\hline & 60 & 333.33 & 0.07 & 0.9801 & 63.55 & 2.95 & 0.9462 & 63.38 & -- & 0.9542 \\
\hline Alluvium + & 30 & 178.57 & 0.34 & 0.9831 & 114.71 & 10.49 & 0.3776 & 13.87 & 113.87 & 0.3404 \\
\hline $\mathrm{CK}$ & 60 & 144.93 & -- & 0.9879 & 114.26 & 10.49 & 0.3283 & 13.42 & 114.97 & 0.2906 \\
\hline Alluvium & 30 & 68.49 & 2.18 & 0.9536 & 133.72 & -- & 0.3434 & - & 135.90 & 0.4443 \\
\hline$+\mathrm{M}_{1}$ & 60 & 13.25 & -- & 0.9197 & 157.80 & -- & 0.4943 & -- & 87.91 & 0.4123 \\
\hline Alluvium + & 30 & 86.96 & -- & 0.9499 & 177.42 & - & 0.0772 & -- & 170.30 & 0.0410 \\
\hline $\mathrm{M}_{2}$ & 60 & 70.42 & -- & 0.8735 & 165.39 & - & 0.0141 & -- & 225.35 & 0.1730 \\
\hline
\end{tabular}

Note: K1, binding energy; b1, adsorption maximum; R2, coefficient of determination; $\mathrm{K}$ and $\mathrm{n}$ are empirical constants; A and B are constants.

\subsection{Adsorption Isotherm Fitting and Parameter Analysis of the Incubated Soil Samples}

The adsorption isotherms of all treatment groups were fitted using the Langmuir, Freundlich, and Temkin equations. The fitting parameters and coefficients of determination are presented in Table 3 .
The adsorption isotherms of all treatment groups for soil derived from basalt fitted well with all three adsorption models. For the groups derived from granite and alluvium, the adsorption isotherms of both groups were best fitted by the Langmuir equation, followed by the Freundlich and Temkin equations. 
Maximum $\mathrm{P}$ buffering capacity (MPBC) is the product of parameters $\mathrm{k}$ and $\mathrm{b}$ in the Langmuir equation, and is an important index for the evaluation of soil P-fixation capacity and fixation rate. The MPBC values of the three soil types treated with organic matter followed by 30 or 60 days of incubation are shown in Table 4 .

The addition of $\mathrm{M}_{1}$ followed by 30 days of incubation decreased the MPBC of soil derived from basalt, but increased that of soils derived from granite and alluvium.

In contrast, the addition of $\mathrm{M}_{2}$ caused the MPBC of soils derived from basalt and alluvium to decrease, but that of soil derived from granite to increase. The addition of M1 followed by 60 days of incubation decreased the MPBC of soils derived from basalt and alluvium, but increased that of soil derived from granite, whereas the addition of $\mathrm{M}_{2}$ decreased the MPBC of soil derived from basalt, but increased that of soils derived from granite and alluvium.

The MPBC and the adsorption capacity of soil derived from basalt decreased after the addition of organic matter. As shown by the current study, the addition of organic matter to the soil generated various interactions with soil colloids. This interaction reduced the P-absorption capacity of the soil, which subsequently led to a decrease in the MPBC. For soils derived from granite and alluvium, the addition of organic fertilizers led to unstable changes in the MPBC. Several factors might have caused this phenomenon, including the composition of the introduced organic fertilizers, the soil incubation period and the parent material of the soil. Further investigation is required to obtain a better understanding of the factors relating to this phenomenon.

Table 4. MPBC and SPR of the three different soil types with organic matter application and incubation

\begin{tabular}{|c|c|c|c|c|}
\hline \multirow{2}{*}{$\begin{array}{l}\text { Soil Type \& } \\
\text { Treatment }\end{array}$} & \multicolumn{2}{|c|}{ MPBC $\left(\mathbf{L} \cdot \mathbf{k g}^{-1}\right)$} & \multicolumn{2}{|c|}{ SPR (mg $\left.\mathbf{k g}^{-1}\right)$} \\
\hline & 30 days & 60 days & 30 days & 60 days \\
\hline Basalt $+\mathrm{CK}$ & 500.00 & 666.67 & 94.34 & 121.95 \\
\hline Basalt $+\mathrm{M}_{1}$ & 181.82 & 156.25 & 35.21 & 30.49 \\
\hline Basalt $+M_{2}$ & 400.00 & 312.50 & 75.19 & 59.88 \\
\hline Granite + CK & - & 18.94 & - & 3.74 \\
\hline Granite $+\mathrm{M}_{1}$ & 625.00 & 6.89 & 54.64 & 1.37 \\
\hline Granite $+\mathrm{M}_{2}$ & 28.65 & 22.73 & 5.62 & 4.48 \\
\hline Alluvium + CK & 60.98 & - & 11.42 & - \\
\hline Alluvium $+\mathrm{M}_{1}$ & 149.25 & - & 20.79 & - \\
\hline Alluvium $+\mathrm{M}_{2}$ & - & - & - & - \\
\hline
\end{tabular}


Standard $\mathrm{P}$ retention (SPR) refers to the $\mathrm{P}$ adsorption of soil when the $\mathrm{P}$ solution is $0.2 \mathrm{mg} \cdot \mathrm{L}^{-1}$. The SPR values for the various treatment groups are shown in Table 4. For all treatment groups of soil derived from basalt, the addition of $\mathrm{PM}$ and $\mathrm{M}_{2}$ followed by 30 or 60 days of incubation decreased the soil SPR. For the groups derived from granite, the addition of both types of organic matter followed by 30 days of incubation increased the soil SPR; however, the soil SPR decreased after 60 days. For the groups derived from alluvium, PM treatment followed by 30 days of incubation increased the soil SPR; however, the soil SPR decreased after 60 days. Treatment with $\mathrm{M}_{2}$ followed by 30 days of incubation decreased the soil SPR; however, soil SPR increased after 60 days. These differences might have been caused by the effect of long-term fertilization of soils derived from granite and alluvium, which led to a high $\mathrm{P}$ content in the soils. Therefore, the negative SPR values calculated from the fitted curves might be due to deviations from the high base P levels in the soils.

\section{Conclusions}

The addition of $M_{1}$ and $M_{2}$ followed by 30 or 60 days of incubation increased the availability of $\mathrm{P}$ in soils derived from all three parent materials, with available $\mathrm{P}$ decreasing with increasing incubation time. The organic matter content of all three soil types was similar to that of available $\mathrm{P}$ after the addition of $\mathrm{M}_{1}$ and $\mathrm{M}_{2}$ followed by incubation.

In general, the addition of organic matter followed by incubation caused a decrease in the P-adsorption capacity of soil derived from basalt, thereby increasing the risk of $\mathrm{P}$ pollution. For soils derived from granite and alluvium, the addition of $M_{1}$ followed by incubation decreased the P-adsorption capacity, whereas the addition of $M_{2}$ followed by incubation caused it to increase.
The results of equation-fitting showed that soil derived from basalt fitted well with all three equations, whereas soils derived from granite and alluvium fitted the Langmuir equation the best, followed by the Freundlich and Temkin equations.

The addition of $M_{1}$ and $M_{2}$ followed by incubation reduced the MPBC and SPR of soil derived from basalt. For soils derived from granite and alluvium, different increases and decreases in MPBC and SPR were observed. These differences were due to disparities in the soil parent material and incubation time, as well as differences in the types of organic material. This implied that the amount of P fertilizer needed to be applied to the soil was lowered by the addition of the manure in the soil derived from basalt.

\section{Acknowledgment}

We acknowledge financial support from the State Nature Science Foundation of China (31201693), the Science and technology Foundation of Guangdong province (2011B020309004) and the Scientific Research Foundation of the Guangdong Academy of Sciences (qnjj201011).

\section{References}

Agbenin, J.O., Igbokwe, S.O. 2006. Effect of soildung manure incubation on the solubility and retention of applied phosphate by a weathered tropical semi-arid soil. Geoderma. 133, 191-203.

Azeez, J.O., Van Averbeke, W. 2011. Effect of manure types and period of incubation on phosphorus-sorption indices of a weathered tropical soil. Commun. Soil Sci. Plan. Anal. 42, 2200-2218.

Bolster, C.H., Sistani K.R. 2009. Sorption of phosphorus from swine dairy and poultry manures. Commun. Soil Sci. Plan. Anal. 40, 1106-1123. 
Dossa, E.L., Bakam, J., Kkouma, M. 2008. Phosphorus sorption and desorption in semiarid soils of Senegal amended with native shrub residues. Soil Sci. 173, 669-682.

Donald, L.S. 2003. Environmental soil chemistry. Academic Press, San Diego.

Essington, M.E. 2003. Soil and water chemistry, An integrative approach. CRC Press, Boca Raton, FL.

Gichangi, E.M., Mnkeni, P.N.S. 2009. Effects of goat manure and lime addition on phosphate sorption by two soils from the Transkei Region, South Africa. Commun. Soil Sci. Plan. Anal. 40(21-22), 3335-3347.

Guppy, C.N., Menzies, N.W., Moody, P.W., Blamey, F.P.C. 2005. Competitive sorption reactions between phosphorus organic matter in soil: A review. Aust. J. Soil Res. 43, 189-202.

Hunt, J.F., Ohno, T., He, Z., Honeycutt, C.W., Dail, D.B. 2007. Inhibition of phosphorus sorption to goethite, gibbsite, and kaolin by fresh and decomposed organic matter. Biol. Fert. Soil 44, 277-288

Hua, Q., Li, J., Zhou, J. 2008. Enhancement of phosphorus solubility by humic substances in Ferrosols. Pedosphere. 18(4), 533-538.

Hue, N.V. 1991. Effect of organic acids/anions on $\mathrm{P}$ sorption and phytoavailability in soils with different mineralogies. Soil Science. 152, 463-471.

Iyamuremye, F., Dick, R.P. 1996. Organic amendments and phosphorus sorption. Adv. Agronomy. 56, 139-185.

Kinniburgh D.G. 1986. General purpose adsorption isotherms. Environ. Sci. Technol. 20, 895-904.

Kou, C., Wang, Q., Ren, L. 1999. Study on the variety of wheat and peanut in utilization in different phosphorus compound. China J. Soil Sci. 30, 181184.

Lei, H., Zhu, C., Liu, X. 2004. Phosphorus adsorptiondesorption characteristics in acid soils under amendment. Acta Pedologica Sinica. 41, 636-640.

Loppert, R.H., Inskeep W.P. 1996. Iron. In: J. M. Bigham (ed). Methods of soil analysis. Part 3. Chemical methods. SSSA, Book series No.5. Madison, WI:SSSA, pp: 639-634.

Liu, J., Zhang, F. 2000. Dynamics of soil P pool in a long-term fertilizing experiment of wheat-maize rotation II. Dynamics of soil Olsen-P and inorganic P. China J. Appl. Ecol. 11, 360-364.

McKeague, J.A., Day, J.H. 1966. Dithionite and oxalate extractable $\mathrm{Fe}$ and $\mathrm{Al}$ as acids in differentiating various classes of soils. Can. J. Soil Sci.46, 13-22.

Ma, L., Xu, R. 2010. Effects of regulation of $\mathrm{pH}$ and application of organic material adsorption and desorption of phosphorus in three types of acid soils. J. Ecol. Rural Environ. 26, 596-599.

McBeath, T.M., Armstrong, R.D., Lombi, E., Mclaughlin, M.J. Holloway, R.E. 2005. Responsiveness of wheat (Triticum aestivum) to liquid and granular phosphorus fertilizers in southern Australian soils. Aust. J. Soil Res. 43, 203-212.

McGechan, M.B., Lewis D.R. 2002. Sorption of phosphorus by soil, part 1, principles, equations and models. Biosyst. Eng. 82, 1-24.

Ministry of Agriculture of the People's Republic of China. 2012. NY525-2012 Agricultural industry standard of the People's Republic of China, organic fertilizer. Beijing, China Agricultural Press.

Murphey, J., Riley, J.P. 1962. A modified single solution method for determination of phosphate in natural waters. Analytica Chimica Acta. 27, 31-36. 
Olsen, S.R., Cole, C.V., Watanabe, F.S., Dean, L.A. 1954. Estimation of available phosphorus in soils by extraction with sodium bicarbonate (USDA Circular 939), Washington, D. C. U.S. Government Printing Office.

Pant, H.K., Reddy, K.R. 2001. Phosphorus sorption characteristics of estuarine soils under different redox conditions. J. Environ. Qual. 30, 1474-1480.

Shariatmadari H., Shirvani M., Jafari A. 2006. Phosphorus release kinetics and availability in calcareous soils of selected arid and semiarid toposequence. Geoderma. 132, 261-272.

Violante, A., Huang, P.M. 1989. Influence of oxidation treatment on surface properties and reactivities of short-range ordered precipitates of aluminium. Soil Sci. Society Am. J. 53, 1402-1407.

Withers, P.J.A., Jarvie, H.P. 2008. Delivery and cycling of phosphorus in rivers, A review. Sci. Total Environ. 400, 379-395.
Zhao, X., Zhong, X., Li, G. 2006. The evaluation of phosphorus leaching risk of 23 Chinese soils II. The relationships between soils properties, $\mathrm{P}$ adsorption characteristics and the leaching criterion. Acta Ecologica Sinica. 26, 3011-3017.

Zhang, A., He, L., Zhao, H., Wu, Z. 2009. Effect of organic acids on inorganic phosphorus transformation in soil with different phosphorus sources. China J. Appl. Environ. Biol. 15(4), 474478.

Zhuo, A., He, L., Zhao, H. 2009a. Effect of organic acids on inorganic phosphorus transformation in soils and its readily available phosphate. Acta Ecologica Sinica. 29(8), 4061-4069.

Zhuo, A., He, L., Zhao, H. 2009b. Effect of organic acids on inorganic phosphorus transformation in soil with different phosphorus sources. China J. Appl. Environ. Biol. 15, 474-478. 